\title{
Peningkatan Kemampuan Memahami Teks Bacaan Bahasa Jerman dengan Teknik Scanning Reading
}

\author{
Haslinda \\ Universitas Muhamamdiyah Makassar \\ haslindabachtiar@unismuh.ac.id \\ Orcid ID https://orcid.org/0000-0001-8541-0823
}

\begin{abstract}
Article received
:2021-06-10

Review process : 2021-06-10

Article published : 2021-06-15
\end{abstract}

\begin{abstract}
The problem of this research is about the low ability to understand German reading texts. It aims to find out the results of increasing the ability to understand German reading texts with scanning reading techniques at SMA Negeri 10 Makassar. This research is classified into classroom action research. Data collection techniques were obtained through observation, documentation analysis, and the reflection stage. The results showed that the scanning reading technique could improve the ability to understand German reading texts for class XI IPA 1 SMA Negeri 10 Makassar. In the first cycle, it was found that $32(80 \%)$ students had reading speed using scanning reading techniques with low qualifications, while $8(20 \%)$ students had moderate reading skills. At the level of understanding in the medium category are as many as 31 (77.5\%) students and the level of understanding in the high category are as many as $9(22.5 \%)$ students. In the second cycle, it was found that all students, as many as $40(100 \%)$ students were declared successful in reading with the scanning reading technique with moderate qualifications. Meanwhile, the level of understanding in the very high category was 6 (15\%) students and those with the high category were 34 (85\%) students and none of the students had a very low level of understanding. This means that the level of understanding German texts with the scanning reading technique of class XI IPA I SMA Negeri 10 students in cycle II is declared successful
\end{abstract}

Keywords : German Text Reading, Scanning Reading Techniques

Abstrak: Masalah penelitian ini tentang rendahnya kemampuan memahami teks bacaan bahasa jerman. Hal ini bertujuan untuk mengetahui hasil peningkatan kemampuan memahami teks bacaan bahasa Jerman dengan teknik scanning reading di SMA Negeri 10 Makassar. Penelitian ini digolongkan ke dalam penelitian tindakan kelas. Teknik pengumpulan data diperoleh melalui hasil observasi, analisis dokumentasi, serta tahap refleksi. Hasil penelitian menunjukkan bahwa teknik scanning reading dapat meningkatkan kemampuan memahami teks bacaan bahasa Jerman siswa kelas XI IPA 1 SMA Negeri 10 Makassar. Pada siklus I diketahui bahwa siswa yang memiliki kecepatan membaca dengan teknik scanning reading dengan kualifikasi rendah sebanyak 32 (80\%) siswa sedangkan siswa yang memiliki kemampuan membaca dengan kualifikasi sedang sebanyak 8 $(20 \%)$ siswa. Pada Tingkat pemahaman dengan kategori sedang adalah sebanyak adalah sebanyak 31 (77,5\%) siswa dan tingkat pemahaman dengan kategori tinggi adalah sebanyak 9 (22,5\%) siswa. Pada siklus II diketahui bahwa semua siswa yaitu sebanyak 40 (100\%) siswa dinyatakan berhasil membaca dengan teknik scanning reading dengan kualifikasi sedang. Sedangkan tingkat pemahaman dengan kategori sangat tinggi adalah sebanyak 6 (15\%) siswa dan yang memiliki kategori tinggi adalah sebanyak 34 (85\%) siswa dan tidak ada satupun siswa yang memiliki tingkat pemahaan dengan kategori sangat rendah. Artinya Tingkat memahami teks bahasa Jerman dengan teknik scanning reading siswa kelas XI IPA 1 SMA Negeri 10 pada siklus II dinyatakan berhasil.

Kata Kunci: Teks Bacaan Bahasa Jerman, Teknik Scanning Reading 


\section{Pendahuluan}

Perkembangan ilmu pengetahuan dan teknologi menuntut terciptanya masyarakat yang gemar belajar. Proses belajar yang efektif antara lain dilakukan melalui membaca. Masyarakat yang gemar membaca memperoleh pengetahuan dan wawasan baru yang akan meningkatkan kecerdasannya sehingga mereka lebih mampu menjawab tantangan hidup pada masa-masa mendatang. Dalam dunia pendidikan aktivitas dan tugas membaca merupakan suatu hal yang tidak dapat ditawar-tawar. Sebagian besar pemerolehan ilmu yang dilakukan oleh siswa atau mahasiswa melalui aktivitas membaca. Keberhasilan studi seseorang akan sangat ditentukan oleh kemampuan dan kemauan membaca. Bahkan setelah seorang siswa menyelesaikan studinya, kemampuan dan kemauan membaca tersebut akan sangat mempengaruhi keluasan pandangan tentang berbagai masalah. Oleh karena itu, pengajaran bahasa yang mempunyai tugas membina dan meningkatkan kemampuan membaca siswa hendaknya menaruh perhatian yang cukup terhadap usaha peningkatan kemampuan dan kemauan membaca para siswa.

Melalui membaca, orang dapat memperoleh pengalaman baru menjelajahi batas ruang dan waktu. Segala peristiwa yang terjadi di tempat lain di masa lampau atau di masa sekarang atau kemungkinan kejadian di masa yang akan datang dapat diketahui dan dicermati oleh pembaca. Demikian pula, antara tujuan membaca dengan penerapan teknik membaca. Sebenarnya orang dapat mengefisienkan waktu dan tenaganya dalam membaca. Tujuan membaca tertentu menuntut teknik membaca tertentu pula. Jadi benar, bila seseorang yang tahu teknik membaca, akan dapat menjelaskan antara tujuan membaca dengan teknik membaca.

Agar dapat memanfaatkan waktu dengan efisien dalam membaca, maka siswa perlu memiliki keterampilan membaca cepat disertai dengan pemahaman terhadap isi bacaan yang dibaca. Upaya memiliki kemampuan membaca cepat, siswa dapat dipermudah melalui membaca berbagai sumber, baik melalui buku maupun internet. Hal inilah yang perlu mendapat perhatian guru bahasa khususnya bahasa Jerman di sekolah. Salah satu teknik membaca adalah teknik scanning. Teknik scanning adalah teknik membaca cepat yaitu untuk mencari kata atau jawaban secara cepat dari suatu pertanyaan tertentu.

Pada hakikatnya, membaca pemahaman adalah kegiatan membaca yang dimaksudkan untuk memahami makna yang terkandung di dalam suatu teks. Pemahaman suatu teks sangat bergantung pada berbagai hal. Salah satu yang perlu mendapat perhatian dalam membaca adalah keterampilan yang dimiliki oleh seorang pembaca dalam memahami teks yang dibaca. Tinggi rendahnya keterampilan yang dimiliki pembaca akan sangat berpengaruh pada tingkat pemahaman pada teks yang dibaca. Membaca scanning (memindai) merupakan bagian dari membaca cepat. Dalam dunia pendidikan, peranan membaca terhadap peningkatan prestasi siswa sangat besar. Dengan kemampuan membaca cepat yang baik perkembangan berpikir kritis siswa semakin meningkat dengan cepat. Hal ini dapat dilihat pada kenyataan, bahwa semakin tinggi tingkat kemampuan membaca siswa, semakin tinggi pula tingkat pemahaman pengetahuan yang dimilikinya. Dengan demikian, minat baca dan kemampuan membaca cepat siswa perlu ditumbuhkan sedini mungkin agar siswa dapat memahami peranan dan fungsi membaca cepat, baik sebagai alat komunikasi maupun sebagai alat belajar untuk mengembangkan pengetahuan, kecerdasan, wawasan kepribadian, kreativitas, dan daya nalarnya.

Rendahnya kemampuan membaca telah diungkapkan pada peneliti sebelumnya. Sugiarni (2003) mengemukakan bahwa kemampuan membaca dengan teknik skimming bahasa Jerman siswa kelas XI IPA SMA Negeri 3 Makassar yaitu 61,08 \% atau dengan kata lain kemampuan siswa masih rendah. Begitu pula dari hasil penelitian Cilellang (2004) menyatakan bahwa kemampuan membaca memahami teks bahasa Jerman siswa kelas III 
bahasa SMA Negeri 1 Sinjai yaitu $60,78 \%$ atau dengan kata lain masih juga rendah, karena belum mencapai standar atau kriteria yang telah ditentukan, yakni 65\%.

Teknik scanning reading merupakan teknik belajar yang membantu guru untuk meningkatkan pemahaman siswa terhadap suatu bacaan untuk menemukan ide pokok secara cepat dan efisien serta untuk membantu mendapatkan informasi tanpa membaca yang lainlain, langsung ke masalah yang dicari. Berdasarkan permasalahan tersebut, maka penulis tertarik untuk mengadakan penelitian ini.

SMA Negeri 10 Makassar beralamat di jalan Tamangapa V No 12 Makassar Provinsi Sulawesi Selatan. Alasan peneliti memilih lokasi ini karena kemampuan memahami teks bahasa Jerman di sekolah tersebut masih tergolong rendah, hal ini didapat dari informasi guru mata pelajaran bahasa Jerman di sekolah tersebut bahwa kemampuan memahami teks bacaan bahasa Jerman di sekolah tersebut masih rendah, sehingga peneliti tertarik mengadakan penelitian di sekolah tersebut. Sekolah tersebut juga merupakan tempat peneliti melaksanakan Praktek Pengalaman Lapangan (PPL) sehingga hubungan peneliti dengan guru yang menjadi subjek penelitian sudah kondusif, sehingga segala sesuatu yang sifatnya akademik mudah diselesaikan bila terjadi hal-hal yang sulit dipecahkan dalam pembelajaran bahasa Jerman.

\section{Metode}

Penelitian ini termasuk jenis penelitian tindakan kelas (classroom action research). Penelitian tindakan ini dilakukan untuk menggambarkan dan mengamati proses belajar bahasa Jerman khususnya membaca (lesen) siswa kelas XI SMA Negeri 10 Makassar dengan teknik scanning reading. Pelaksanaan penelitian ini dilakukan dalam bentuk siklus, terdapat empat tahap, yaitu: 1) Perencanaan (planning), 2) Tindakan (action), 3) Pengamatan (observing), dan 4) Refleksi (reflecting). Penelitian tindakan kelas ini adalah salah satu upaya untuk meningkatkan kemampuan memahami teks bacaan bahasa Jerman sehingga guru dapat mengetahui secara jelas masalah-masalah yang ada di kelas dan cara mengatasi masalah tersebut. Populasi penelitian ini adalah seluruh siswa kelas XI IPA yang berjumlah sekitar 240 orang yang terdiri dari 6 kelas. Sampel yang digunakan dalam penelitian ini adalah Purposive Sampling yang dikhususkan pada kelas XI IPA 1 yang berjumlah 40 siswa dengan komposisi laki-laki 13 siswa sedangkan perempuan 27 siswi. Kelas XI IPA 1 dipilih sebagai subjek terteliti berdasarkan pertimbangan bahwa kelas tersebut sedang mempelajari aspek membaca. Fokus penelitian ini adalah peningkatan kemampuan memahami teks bacaan bahasa Jerman dengan teknik scanning reading.

Teknik pengumpulan dan Analisis data yaitu sebelum mengadakan penelitian tindakan kelas terlebih dahulu peneliti mengadakan observasi awal. Adapun langkah-langkah dalam observasi awal yaitu:

1. Menentukan tempat penelitian dan masalah yang akan diteliti.

2. Mengurus surat izin penelitian.

3. Menjajaki tempat penelitian.

4. Mengumpulkan informasi awal tentang kondisi pengajaran bahasa Jerman siswa kelas XI IPA 1.

Tahap-tahap yang dilaksanakan dalam penelitian tindakan kelas ini mencakup 2 siklus, dimana kedua siklus tersebut merupakan rangkaian yang saling berkaitan, artinya pelaksanaan siklus II merupakan lanjutan dan perbaikan dari pelaksanaan siklus I. Penelitian ini menggunakan pendekatan kualitatif dan kuantitatif. Data kualitatif dikumpulkan peneliti dari fenomena yang terjadi dari aktivitas guru dan siswa dianalisis secara kualitatif. Sedangkan 
data kuantitatif dikumpulkan dari hasil tes belajar dan dianalisis dengan statistik deskriptif. Penentuan tingkat kecepatan membaca telah diperoleh dari perhitungan kecepatan membaca setiap menitnya $(\mathrm{kpm})$ dilakukan dengan mentransfer jumlah angka yang di dapat kedalam jenjang kualifikasi sebagai berikut:

Tabel 1: Standarisasi Kecepatan Membaca

\begin{tabular}{|c|c|}
\hline Kecepatan membaca & Kualifikasi \\
\hline $175-250 \mathrm{kpm}$ & Rendah \\
\hline $255-350 \mathrm{kpm}$ & Sedang \\
\hline $400-500 \mathrm{kpm}$ & Tinggi \\
\hline
\end{tabular}

Penentuan Tingkat Pemahaman Bacaan, Penentuan tingkat pemahaman bacaan diukur dengan cara menghitung presentase. Skor jawaban ideal/benar dari pertanyaan tes pemahaman bacaan. Jumlah soal pemahaman bacaan, adalah 5 nomor soal berbentuk objektif dengan skor setiap nomor adalah 2. Artinya, jika siswa menjawab dengan benar diberi skor 2 dan jika salah 0 . Hal ini berarti skor idealnya 10.

\section{Hasil dan Pembahasan}

\section{Hasil Perencanaan Siklus I dan II}

Pada siklus I, tema pembelajaran yang disampaikan adalah "lebensmittell" dengan sub pokok bahasan die Wohnung dengan teks bacaan bahasa Jerman yang telah disiapkan sebelumnya. Dalam rencana pembelajaran siklus I ini terdiri dari kompetensi dasar dalam hal ini aspek membaca (lesen), Indikator yang terdiri dari (1) menentukan tema dari wacana tulis (2) membaca dengan teknik scanning reading (3) menjawab pertanyaan dari wacana tulis. Metode pembelajaran yang dilakukan pada siklus I adalah metode ceramah dan pemberian tugas. Adapun langkah-langkah pembelajaran ini dengan alokasi waktu 90 menit terdiri dari pendahuluan: (1) absensi siswa, (2) menginformasikan SK, KD dan indikator yang akan dicapai selama 10 menit. Kegiatan inti: (1) guru menjelaskan sebuah teks bacaan, (2) menugaskan kepada siswa untuk membaca, (3) menugaskan kepada siswa untuk menjawab pertanyaan dari teks bacaan, selama 65 menit dan Penutup: secara bersama-sama guru dan siswa membahas latihan-latihan dan merangkum pelajaran selama 15 menit. Tindakan yang dilakukan pada siklus I ini berupa pelaksanaan dari rencana yang telah disiapkan. Berdasarkan pengamatan memperlihatkan bahwa selama proses belajar mengajar berlangsung, guru memberikan materi teks bacaan tentang "lebensmittel" secara keseluruhan tidak mengalami hambatan dalam pelaksanaan pembelajaran.

Sedangkan perencanaan pembelajarn pada siklus II ini adalah hasil refleksi perencaan pada siklus I, materi pembelajaran sama dengan siklus I yaitu "lebensmittel" dengan sub pokok bahasan die Wohnung. Begitu pula dalam rencana pembelajaran siklus II dari Kompetensi Dasar dalam hal ini aspek membaca (lesen) indikator yang terdiri dari (1) Menentukan tema dari wacana tulis (2) membaca dengan teknik scanning reading menjawab Pertanyaan dari wacana tulis. Metode pembelajaran yang dilakukan pada siklus II adalah metode tanya jawab, ceramah dan pemberian tugas. Adapun langkah-langkah dalam pembelajaran ini dengan alokasi waktu 90 menit terdiri dari Pendahuluan: (1) mengabsen siswa, (2) menginformasikan SK, KD dan Indikator yang akan dicapai (3) guru memusatkan perhatian siswa, dengan memberikan apersepsi yaitu memberikan penjelasan tentang 
pentingnya membaca dan guru memotivasi siswa untuk belajar, kegiatan ini dilakukan selama 15 menit. Kegiatan Inti (1) guru menjelaskan materi yang akan dipelajari (2) guru menjelaskan tentang teknik scanning reading dan cara membaca dengan teknik scanning reading (3) guru menugaskan kepada siswa membaca dengan teknik scanning reading (4) guru menugaskan kepada siswa untuk menjawab pertanyaan dari teks bacaan, selama 65 menit dan Penutup: secara bersama-sama guru dan siswa membahas materi yang telah dipelajari dan merangkum pelajaran selama 10 menit. Berdasarkan pengamatan pada siklus II memperlihatkan bahwa selama proses belajar mengajar berlangsung guru telah memberikan teks bacaan tentang "lebensmittel" dan menggunakan teknik scanning reading dengan baik. Secara keseluruhan kolaborator tidak mengalami hambatan dalam pelaksanaan pembelajaran. Pembelajaran disusun menumbuhkan minat baca siswa, yaitu dengan menggunakan teknik scanning reading.

\section{Hasil Pelaksanaan Siklus I dan II}

Pada siklus I, hasil pengamatan yang dilakukan peneliti terhadap guru bidang studi bahasa Jerman dan siswa di dalam kelas adalah guru kurang memberikan motivasi kepada siswanya, hanya cenderung bercerita atau ceramah dan memberikan tugas kepada siswa. Sehingga para siswa cenderung hanya menyimak perkataan guru dan pembelajaran bersifat menoton atau hanya guru yang aktif di kelas.

Namun pada siklus I terdapat kelemahan maka diadakan refleksi yang berupa renungan terhadap pengalaman mengenai kekurangan dan kelemahan tindakan selama kegiatan pada siklus I, didapat hasil sebagai berikut (1) cara guru kurang memotifasi dan mengarahkan siswa untuk membaca belum maksimal (2) pemahaman siswa terhadap teks bacaan bahasa Jerman belum maksimal (3) siswa acuh tak acuh dalam membaca (4) banyak siswa yang ribut dan kurang memahami penjelasan guru. Secara garis besar pelaksanaan siklus I telah berlangsung dengan baik dan akan dilanjutkan dengan siklus II.

Pelaksanaan siklus II didasarkan atas hasil refleksi pada siklus I. Hasil refleksi pada siklus I menjadi bahan bagi penyusunan perencanaan pada siklus II. Adapun hasil observasi bagi guru dan siswa selama proses belajar mengajar berlangsung pada siklus II ini guru megubah metode mengajarnya dengan metode tanya jawab, menumbuhkan motivasi siswa dalam membaca misalnya dengan cara memberikan, mengemukakan pendapat tentang pelajaran yang telah dipelajari dan memberikan kesempatan kepada siswa untuk menyampaikan apa-apa yang menjadi kendala siswa dalam memahami teks bacaan bahasa Jerman.

\section{Hasil Tes Kemampuan Membaca dan Memahami Teks Bacaan Bahasa Jerman}

Pada akhir pelaksanaan tindakan pada siklus I, peneliti melakukan tes kemampuan membaca dengan teknik scanning reading g hasilnya sebagai berikut:

Tabel 2: Tingkat Kecepatan Membaca Teks Bahasa Jerman Siklus I

\begin{tabular}{|c|c|c|c|}
\hline Kecepatan Membaca & Kualifikasi & Frekuensi & Presentase \\
\hline $400-500 \mathrm{kpm}$ & Tinggi efektif & - & - \\
\hline $255-350 \mathrm{kpm}$ & Sedang & 8 & $20 \%$ \\
\hline $175-250 \mathrm{kpm}$ & Rendah & 32 & $80 \%$ \\
\hline & & 40 & $100 \%$ \\
\hline
\end{tabular}


Berdasarkan data, diketahui bahwa siswa yang memiliki kemampuan membaca cepat dengan teknik scanning reading dengan kecepatan membaca 175-250 kpm dengan kualifikasi rendah adalah sebanyak 32 siswa (80\%) dari 40 siswa. Sedangkan siswa yang memiliki kemampuan membaca dengan kecepatan 255-350 kpm dengan kualifikasi sedang adalah sebanyak 8 siswa $(20 \%)$ dari 40 siswa. Dan tidak satupun siswa yang mencapai kategori tinggi dengan kecepatan antara $400-500 \mathrm{kpm}$. Artinya teknik scanning reading dalam memahami teks bacaan bahasa Jerman siswa kelas XI IPA 1 SMA Negeri 10 Makassar pada siklus I belum berhasil dan akan diperbaiki pada siklus II. Sedangkan $8(20 \%)$ orang yang dinyatakan sudah berhasil dengan kualifikasi sedang dipertahankan pada siklus II.

Pada akhir pelaksanaan tindakan pada siklus II, peneliti melakukan tes kemampuan membaca dengan teknik scanning reading yang hasilnya sebagai berikut:

Tabel 3: Tingkat Kecepatan Membaca Teks Bahasa Jerman Siklus II

\begin{tabular}{|c|c|c|c|}
\hline Kecepatan Membaca & Kualifikasi & Frekuensi & Presentase \\
\hline $400-500 \mathrm{kpm}$ & Tinggi efektif & - & - \\
\hline $255-350 \mathrm{kpm}$ & Sedang & 40 & $100 \%$ \\
\hline $175-250 \mathrm{kpm}$ & Rendah & - & - \\
\hline & & 40 & $100 \%$ \\
\hline
\end{tabular}

Tabel di atas menunjukkan bahwa tidak ada siswa yang memiliki kecepatan membaca 175-250 kpm yang berkategori rendah jadi dapat disimpulkan bahwa kemampuan membaca dengan teknik scanning reading siswa kelas XI IPA 1 SMA Negeri 10 Makassar pada siklus II dinyatakan berhasil berkat refleksi yang dilakukan pada siklus I.

Pada akhir pelaksanaan tindakan siklus I, peneliti melakukan tes kemampuan memahami teks bacaan bahasa Jerman dengan teknik scanning reading yang hasilnya sebagai berikut:

\section{Tabel 4: Tingkat Kemampuan Memahami Teks Bacaan Bahasa Jerman Siklus I}

\begin{tabular}{|c|c|c|c|}
\hline Tingkat Pemahaman & Kategori & Frekuensi & Presentase \\
\hline $84 \%-100 \%$ & Sangat Tinggi & - & - \\
\hline $63 \%-83 \%$ & Tinggi & 9 & $22,5 \%$ \\
\hline $42 \%-62 \%$ & Sedang & 31 & $77,5 \%$ \\
\hline $21 \%-41 \%$ & Rendah & - & - \\
\hline $0 \%-20 \%$ & Sangat Rendah & - & - \\
\hline & & 40 & $100 \%$ \\
\hline
\end{tabular}

Data di atas menunjukkan bahwa siswa yang memiliki kemampuan memahami teks bacaan bahasa Jerman dengan teknik scanning reading dengan tingkat pemahaman $42 \%-62 \%$ dengan kategori sedang adalah sebanyak 31 siswa (77,5\%) dari 40 siswa. Sedangkan siswa yang memiliki tingkat pemahaman 63\%-83\% dengan kategori tinggi adalah sebanyak 9 siswa $(22,5 \%)$ dari 40 siswa. Dan tidak satupun siswa yang memiliki tingkat pemahaan $84 \%-100 \%$ dengan kategori sangat tinggi. Artinya, tingkat pemahaman teks bahasa Jerman dengan teknik scanning reading siswa kelas XI IPA 1 SMA Negeri 10 Makassar pada siklus I belum berhasil dan akan diperbaiki pada siklus 2. Sedangkan $9(22,5 \%)$ orang yang dinyatakan sudah berhasil dengan kategori tinggi akan dipertahankan pada siklus dua II. 
Pada akhir pelaksanaan tindakan pada siklus II, peneliti melakukan tes kemampuan memahami teks bacaan bahasa Jerman dengan teknik scanning reading yang hasilnya dapat dilihat pada tabel berikut:

Tabel 5: Tingkat Kemampuan Memahami Teks Bacaan Bahasa Jerman Siklus II

\begin{tabular}{|c|c|c|c|}
\hline Tingkat Pemahaman & Kategori & Frekuensi & Presentase \\
\hline $84 \%-100 \%$ & Sangat Tinggi & 6 & $15 \%$ \\
\hline $63 \%-83 \%$ & Tinggi & 34 & $85 \%$ \\
\hline $42 \%-62 \%$ & Sedang & - & - \\
\hline $21 \%-41 \%$ & Rendah & - & - \\
\hline $0 \%-20 \%$ & Sangat Rendah & - & - \\
\hline \multicolumn{2}{|r}{} & 40 & $100 \%$ \\
\hline
\end{tabular}

Berdasarkan tabel, diketahui bahwa siswa yang memiliki kemampuan memahami teks bacaan bahasa Jerman dengan teknik scanning reading dengan tingkat pemahaman $84 \%$ $100 \%$ dengan kategori sangat tinggi adalah sebanyak 6 siswa (15\%) dari 40 siswa. Sedangkan siswa yang memiliki tingkat pemahaman $63 \%-82 \%$ dengan kategori tinggi adalah sebanyak 34 siswa (85\%) dari 40 siswa. Dan tidak satupun siswa yang memiliki tingkat pemahaan $21 \%-41 \%$ dengan kategori sangat rendah. Artinya, tingkat pemahaman teks bahasa Jerman dengan teknik scanning reading siswa kelas XI IPA 1 SMA Negeri 10 pada siklus II dinyatakan berhasil berkat refleksi yang dilakukan pada siklus I.

Berdaskan tabel di atas dapat disimpulkan bahwa kemampuan membaca dan memahami teks bahasa Jerman dengan teknik scanning reading mengalami peningkatan dari siklus I ke siklus II. Hal ini berkat refleksi yang dilakukan pada akhir siklus I.

\section{Kesimpulan}

Kesimpulan yang dapat di kemukakan setelah pelaksanaan penelitian ini adalah sebagai berikut: Pada siklus I diketahui bahwa siswa yang memiliki kecepatan membaca dengan teknik scanning reading dengan kualifikasi sedang sebanyak 8 siswa dari 40 siswa sedangkan siswa yang memiliki kemampuan membaca dengan kualifikasi rendah sebanyak 32 siswa dari 40 siswa. Pada Tingkat pemahaman dengan kategori tinggi sedang sebanyak 9 siswa dari 40 siswa dan tingkat pemahaman dengan kategori tinggi adalah sebanyak 31 siswa dari 40 siswa. Pada siklus II diketahui bahwa semua siswa yaitu sebanyak 40 siswa dinyatakan berhasil dalam membaca dengan teknik scanning reading dengan kualifikasi sedang. Sedangkan pada tingkat pemahaman dengan kategori sangat tinggi adalah sebanyak 6 siswa dari 40 siswa dan siswa yang memiliki kategori tinggi adalah sebanyak 34 siswa dari 40 siswa dan tidak satupun siswa yang memiliki tingkat pemahaan dengan kategori sangat rendah. (dapat dilihat pada tabel 4.2 dan tabel 4.4). Artinya, tingkat pemahaman teks bahasa Jerman dengan teknik scanning reading siswa kelas XI IPA 1 SMA Negeri 10 pada siklus II dinyatakan berhasil karena terjadi peningkatan berkat refleksi yang dilakukan pada siklus I. 


\section{Daftar Rujukan}

Cilellang, Baso. 2004. Kemampuan Memahami Teks Bahasa Jerman Siswa Kelas XII Bahasa SMA Negeri 1 Sinjai. Skripsi. Makassar: FBS UNM.

Harras dan Lilis, S. 2007. Materi Pokok Membaca 1. Jakarta: Universitas Terbuka.

Irmawati. 2010. Kemampuan Membaca Teks Bahasa Jerman Siswa Kelas XI Bahasa SMA Negeri 1 Bantimurung. Skripsi. Makassar: FBS UNM.

Iskandar. 2009. Penelitian Tindakan Kelas. Cipayung Ciputat: Gaung Persada Press. Marbun, Eva M, Rosana Helmi. 2008. Kontakte Deutsch Ekstra. Jakarta: Katalis.

Rahim Farida. 2008. Pengajaran Membaca di Sekolah Dasar. Jakarta: Bumi Aksara Sibylle, Bolton. 1995. Probleme der Leistungsmessung. München: Gothe Institute.

Soedarso. 2006. Speed Reading Sistem Membaca Cepat dan Efektif. Jakarta: Gramedia.

Tampubolon, D.P. 1987. Kemampuan Membaca dan Teknik Membaca Efektif dan Efisien, Bandung: Angkasa

Tarigan, Henry Guntur. 2008. Membaca Sebagai Suatu Keterampilan Berbahasa. Bandung: Angkasa.

Willenberg Heine. 1999. Lesen und Lernen. Berlin: Spektrum Akademische Verlag. 